\title{
POST-PRINT
}

Bonsignori, V., S. Bruti and A. Sandrelli (2018) "Paolo Virzì's glocal comedy in English subtitles: An investigation into linguistic and cultural representation", in S. Zanotti and I. Ranzato (eds) Translating Telecinematic Texts, Thematic Issue of Perspectives: Studies in Translation Theory and Practice. (Print ISSN: 0907-676X; Online ISSN: 1747-6623) DOI: 10.1080/0907676X.2018.1439511

\section{Paolo Virzìs glocal comedy in English subtitles: An investigation into linguistic and cultural representation ${ }^{1}$}

\begin{abstract}
Paolo Virzì's film production is deeply rooted in Italian (often Tuscan) contemporary society, with a focus on the daily lives of ordinary people and the difference between their true selves and their public persona. The language spoken by his colourful characters, which includes regionalisms, slang, colloquialisms and a vast array of idiosyncratic traits, is the quintessence of Virzì's world and of his bitter-sweet irony. In this contribution we aim to illustrate how these culture-specific scenarios are transposed in the English subtitled versions of 3 recent Virzì films, namely La prima cosa bella (2010), Tutti i santi giorni (2012), and Il capitale umano (2014). In this study we identify the indices of regional or Italian identity, linguistically or culturally expressed, in the three aforementioned films, with a view to elucidating the difficulties behind their translation in the English subtitles.
\end{abstract}

Keywords: representation; subtitles; idiolects; regionalisms; colloquialisms.

\section{Introduction}

Since his début in the early 1990s, Italian director Paolo Virzì's trademark style has been the realistic depiction of characters and their environments (Accardo \& Acerbo, 2010): linguistically, this translates into the adoption of the appropriate regional varieties, sociolects and slang. In his films, regional characterisation is no mere stereotyping, but rather the key to gain access to the specific reality portrayed on the screen: "[ ...] la coloritura regionale della lingua [...] si trasforma

\footnotetext{
${ }^{1}$ Although the research was carried out jointly by the three authors, Veronica Bonsignori wrote sections 1.1, 3.and 3.1.; Silvia Bruti wrote sections 4., 4.1., 4.2. and 5; and Annalisa Sandrelli wrote sections 1., 2., 2.1. and 2.2.
} 
nel mezzo privilegiato per accedere a un piccolo mondo di piccole cose che sarebbero irrappresentabili al di fuori di un orizzonte culturalmente e linguisticamente localistico"2 (Malavasi, 2011, p. 91). In this sense, Giordano (2011) defines Paolo Virzì as a glocal director: paradoxically, it is the local scale of his films, with their realism and attention to minute details, which gives them breadth and a universal appeal.

Several translation scholars have remarked on one of the key constraints in subtitling, namely the diamesic shift from spoken to written language, which becomes even more apparent when film dialogue includes several language varieties: although the subtitles are expected to reflect at least some features of orality, when there are dialects, regiolects or sociolects involved, there is a general tendency to standardisation in the target language (De Meo, 2012; Ellender, 2015; Tortoriello, 2012). Given the importance of linguistic variation in the dialogues of Virzì's films, it is interesting to examine their English subtitled versions to determine to what extent and how the latter manage to preserve their "glocal" flavour.

\subsection{Methodology and data}

The films analysed in this paper are La prima cosa bella (2010), Tutti i santi giorni (2012), and Il capitale umano (2014), set in Livorno, Rome and Brianza (Northern Italy), respectively. They were chosen because they contain examples of regiolects from the north, the centre and the south of Italy, as well as specific sociolects and idiolects. Each in its own style and genre - human comedy, ranging from the bitter to the sentimental, verging on the noir in Il capitale umano - the three films depict human beings in their daily lives, focussing on their ambitions and desires, on generational conflicts, on the difference between the characters' true selves and their external projections (or "public faces"). The films also share a personal use of the idiolects spoken by most of the

\footnotetext{
2 "the regional color of the language [...] becomes the key to access a small world of small things which would be impossible to portray beyond a culturally and linguistically provincial viewpoint" (our translation).
} 
characters, which is a blend of regional expressions, slang and colloquialisms. If on the one hand these features are typical of Virzì's signature style, on the other they present pitfalls to translators who are faced with the task of relocating them in a different lingua-culture.

The film director, who was informed about our project from the start, provided us with the dialogue lists and subtitle lists of the three films under analysis. ${ }^{3}$ The lists were merged and converted into full transcripts which are arranged into three columns: starting from the left, the first one contains the speakers' names for each line of dialogue, the central one the Italian (source language) dialogues and the last one on the right the English (target language) subtitles. The table format and the transcription conventions are those of the Dubtalk project. ${ }^{4}$

The subtitles in American English were commissioned to the same company for all three films, namely Laser S. Film s.r.l. in Rome. Table 1 below summarises key information on the films under investigation. As can be noticed, the number of tokens (i.e. overall number of running words) in the subtitles is always lower than in the original dialogues, thus confirming a trend in subtitling: the TL version is condensed in order to allow viewers to read the subtitles whilst watching the film (Antonini, 2005).

Table 1 . The three films under analysis

\section{La prima cosa bella - The First Beautiful Thing}

La prima cosa bella is set in the director's hometown Livorno, in Tuscany, and it is one of Virzì's most personal films, with several autobiographical elements.

\footnotetext{
${ }^{3}$ The authors wish to thank film director Paolo Virzì and his personal assistant Ester Ligori for their collaboration.

${ }^{4}$ Dubtalk is a joint UNINT-University of Pisa project that has created a parallel corpus of contemporary US and UK films and TV series and their Italian dubbed versions. See dubtalk.unint.eu for more details on the transcription conventions and methodology.
} 
The story of the Michelucci family begins in the summer of 1971. The stunningly beautiful Anna is crowned "Most Beautiful Mother" at the annual beauty pageant held at Bagni Pancaldi, a popular bathing establishment in town. Anna is the lively, warm and sometimes embarrassing mother of Bruno and Valeria; her husband, a Carabinieri officer, is violently jealous. The couple repeatedly fight, split up and have other relationships, and the film alternates between flashbacks from Bruno and Valeria's chaotic childhood and scenes set in the present day. Bruno, now a secondary school teacher in Milan, unwillingly returns to Livorno to be at his terminally ill mother's bedside: this coincides with a bittersweet reconciliation for family members, giving both Valeria and himself the strength to move on with their lives.

The film is a true homecoming for the director, as the main "character" in the story may be said to be Livorno itself. The town is visually present in the many landmarks on the screen (the Bagni Pancaldi, the Cinema 4 Mori, the Via Ricasoli shopping area, the canals with their rowing clubs, the exclusive sea-side villas, and so on) and acoustically present in the background music to one of the most poignant scenes (Intermezzo, from local composer Pietro Mascagni's Cavalleria Rusticana, played during Anna's wedding to Loriano at the end of the film) and in the Livornese regiolect spoken by virtually everybody in the film. The only exceptions are Anna's husband Mario, from a small village near Florence, and Sandra, Bruno's girlfriend, who speaks with a Milanese (northern) accent. Most of the cast and extras were selected locally and the few non-Tuscan actors who played Livornese characters (Valerio Mastandrea as adult Bruno, Claudia Pandolfi as adult Valeria, and Micaela Ramazzotti as young Anna) had the help of a dialogue coach.

\subsection{Translating the Livornese regiolect}

Livornese is not an autonomous dialect, but merely a sub-variety of Tuscan with a number of distinctive phonetic, morphological and lexical features. Since all the characters in the film speak with the same accent, there is no need to devise clever ways to represent deviations from standard Italian pronunciation in the English subtitles: it is only worth doing so when one character's speech 
must be marked as different from the others (Chaume, 2012).

As regards morphology, a typical trait is the apocope of the final syllable in infinitives: mangiare (to eat) becomes mangia', vedere (to see) vede' and dormire (to sleep) dormi '; moreover, the negative particle non used in negative verb forms is transformed into ' $u$. Another verb peculiarity is the replacement of first person plural forms with impersonal forms with the si particle: si torna rather than torniamo (we are going back). Typical constructions include the use of double dative pronouns, as in A me mi garberebbe molto (I would like it very much), although in standard Italian either $a m e$ or $m i$ is sufficient. The English subtitles do not attempt to convey any of these features by resorting to ungrammatical structures or marked word order, as sometimes happens in dubbing (Ranzato, 2010).

In terms of lexical choices, there are many words that are recognisably Tuscan and some that belong to the Livornese regiolect specifically. They include verbs such as garbare (Italian piacere, i.e. to like), chetarsi (Italian tacere, i.e. to shut up), and sciagattare (Italian rovinare, i.e. to ruin), which comes from the local Judeo-Livornese bagitto slang. Similarly, there are local adjectives, such as bischero, ciaccino and pillaccherone (i.e. silly chump, busybody and gossip, respectively); idioms, such as dare un picchio (i.e. to hit someone) or è buriana (i.e. it is a mess). All of these regional terms were neutralised in translation: maybe some well-chosen sub-standard English expressions could have been used to preserve some colour.

As dialogues in the film are mostly informal, perhaps the most distinctive lexical features are local discourse markers, interjections, greetings and use of foul language. In this regiolect there are some discourse markers which have no equivalent in English (or in Italian, for that matter). The particles $E$ and $O^{5}$ are used as openers in turn-taking: they are stalling devices which give the speaker time to organise the sentence. As they have no semantic meaning as such, they are merely used to keep the conversation ticking (Example 1).

\footnotetext{
${ }^{5}$ No relation to the Italian conjunctions $e$ and $o$ (namely "and" and "or"), or to the interjections $e h$ and $o h$.
} 
The English subtitle is heavily condensed, with the first part of Anna's line disappearing completely; an extended translation could have conveyed Anna's surprise more fully, such as "What on earth are you wearing?".

Similarly, the interjections dé, boia and boia dé are pragmatically used in responses to express a very wide range of feelings (appreciation, agreement, surprise, disappointment, annoyance, shock, and so on), depending on their position in the sentence and on the speaker's mimicry and intonation. All of these particles were systematically omitted: it would have been possible to attempt a translation of their pragmatic function, if not their local colour. For example, in some cases dé could have been translated as you know or by means of an intensifier (e.g. he's such a bookworm) such as in Example 2.

\begin{tabular}{l|l|c|}
$\begin{array}{l}\text { VALERIA as a } \\
\text { teenager } \\
\text { (voice) }\end{array}$ & $\begin{array}{l}\text { il mil free, fratello Bruno adesso fa } \\
\text { serio... }\end{array}$ & $\begin{array}{l}<\text { My brother Bruno is in high school, lui è uno } \\
\varnothing<\text { he's a bookworm. }>\end{array}$ \\
\hline
\end{tabular}

Another typical discourse marker is $b a d a$ (i.e. look), often shortened to $b a$ ', used to signal mild surprise when meeting someone unexpectedly: it is usually accompanied by a vocative addressing the interlocutor and it is followed by a greeting. In Example 3 a young Bruno catches his father Mario smoking a cigarette after a secret visit to Anna (the two have split up). Mario is startled to see his child awake in the middle of the night (Ba?! Bimbo. $O$ che ci fai qua?) and tries to strike a normal conversation with him, pretending that nothing strange has happened (Allora? Come stai?).

\footnotetext{
${ }^{6}$ In all the examples the items highlighted in bold are the ones discussed in the paper, those in italics correspond to words or expressions that are omitted in the subtitles, and the $\varnothing$ symbol indicates the omission of that feature from the English subtitles.
} 


\begin{tabular}{|c|c|c|}
\hline MARIO & $\begin{array}{l}\text { Ba'! Bimbo. } \boldsymbol{O} \text { che ci fai qua? } \\
\text { Allora? Come stai? Stai bene, sì? } \\
\text { Senti, 'un lo di' a nessuno che } \\
\text { m'hai visto, eh. Intesi? Anche } \\
\text { alla mamma, no. }\end{array}$ & $\begin{array}{c}\varnothing \text { Son! } \\
\varnothing \text { What are you doing here? } \\
\varnothing \text { How are you? }\end{array}$ \\
\hline $\begin{array}{l}\text { BRUNO (as a } \\
\text { boy) }\end{array}$ & Va bene. & $\begin{array}{c}\text { Are you all right? } \varnothing \\
\varnothing \text { Don't tell anyone you saw me. } \varnothing \\
\text { - Not even mom. } \varnothing \\
\text { - All right. }\end{array}$ \\
\hline
\end{tabular}

Mario's line is full of discourse markers (highlighted in bold) aimed at gaining the child's trust and support. Unfortunately, none of them was translated, and the English subtitles read as if he were interrogating the child. It would have been possible to add a simple "Hey" to the first subtitle to signal his surprise, to use a colloquial register (e.g. "how's things?" rather than "how are you?") and to translate some of the discourse markers (“don't tell anyone you saw me, OK? Not even mom, right?").

As regards foul language, in the SL dialogues there are curses such as vai in culo (i.e. fuck off), mild blasphemies such as Dio bono (rather than buono, i.e. good God!), vulgar expressions such as tornate a favvi $i$ 'azzi vostri (go mind your own fucking business), and many more. Strong language plays an important function in some scenes and it was generally reproduced fairly accurately in the TL subtitles, albeit without local flavour. However, as the impact of such language is far stronger in writing than in speaking (Díaz Cintas \& Remael, 2007), there were occasional omissions. In the example below (4), the subtitler avoided the repetition of Bruno's insult (mi hai rotto i coglioni) in Elena's line:

\begin{tabular}{|c|c|c|}
\hline $\begin{array}{l}\text { (ELENA slaps } \\
\text { him) }\end{array}$ & $\begin{array}{l}\text { Elena, basta, hai rotto i coglioni! } \\
\text { Finiamo questa cazzo di ricerca } \\
\text { così me ne vado. } \\
\text { Ma sei scema? }\end{array}$ & $\begin{array}{c}\text { Elena, } \varnothing \text { you're such a pain in the ass! } \\
\text { Can we do our fucking research? } \varnothing \\
\text { You're nuts! }\end{array}$ \\
\hline ELENA & $\begin{array}{l}\text { "Mi hai rotto i coglioni" lo dici } \\
\text { ai tuoi amici ignoranti di quel }\end{array}$ & $\begin{array}{l}\text { Ø I'm not one of your boorish friends } \\
\text { from your shitty neighborhood. }\end{array}$ \\
\hline
\end{tabular}


troiaio di quartiere dove abiti!

Out of all the regional features analysed in this section, foul language is the only one that was at least partly preserved in translation. There is, however, another aspect that is possibly even more important, and that is ensuring that characters with a specific idiolect have their own voice in translation.

\subsection{Idiolects: Anna}

The leading character in La prima cosa bella is undoubtedly Anna, who exerts a powerful influence on the lives of those surrounding her. Anna is very protective and maternal with her children, whom she tries to shield from the chaos she unwittingly creates in their lives. Linguistically, this is often expressed via diminutives, used to downplay problems or offer a verbal cuddle. Examples include $a$ modino (properly), un gocciolino (a little), un minutino (just a minute), via giù, dammi un bacino (all right then, give me a kiss), and many more. This is a key trait of her speech that was mentioned in interviews by both actresses who play her (as a young woman and as a dying patient). Another interesting character in relation to idiolects is Armando Mansani (Anna's employer in a sports store), who has a marked Livornese accent and a mild stutter. Extract 5 below shows examples of Anna's idiolect and Mansani's stutter in a conversation between them. Anna's use of diminutives (fatturine) disappears completely from the English subtitles; likewise, Armando's lines become fully standardised, with no attempt at reproducing his speech impediment.

(5)

\begin{tabular}{|l|l|c|}
\hline MANSANI & $\begin{array}{l}\text { Non so co-ome hai fatto a vende' } \\
\text { quelle due cerate, era tutto } \\
\text { l'inverno che ce l'avevo sul } \\
\text { groppone. }\end{array}$ & $\begin{array}{c}\varnothing \text { How'd you manage to sell } \\
\text { those wet suits? }\end{array}$ \\
\hline ANNA & $\begin{array}{l}\text { Dé, gli ho fatto uno sconto } \\
\text { esagerato. Le hai viste tutte } \\
\text { queste fatturine in scadenza? }\end{array}$ & $\begin{array}{c}\text { - I couldn't get rid of them. } \\
\text { - I slashed the price. }\end{array}$ \\
\hline MANSANI & $\begin{array}{l}\text { Mi ra- raccomando i fornitori } \\
\text { sempre a fine mese, eh, vanno }\end{array}$ & $\begin{array}{c}\varnothing \text { Demember, the suppliers get paid } \\
\text { They're almost due. } \\
\text { at the end of the month. }\end{array}$ \\
\hline
\end{tabular}




\begin{tabular}{|l|l|c|}
\hline & pagati. & \\
\hline ANNA & $\begin{array}{l}\text { E ricordati le pinne, c’è rimaste } \\
\text { solo taglie grandi. }\end{array}$ & $\begin{array}{c}\text { Order some more flippers, } \\
\text { we only have large sizes left. }\end{array}$ \\
\hline
\end{tabular}

This final example also presents many of the characteristics analysed in $\S 2.1$, and can thus be used as a summary of the translation difficulties posed by the SL dialogues. There are ungrammatical structures (singular auxiliary instead of the plural form in c'è rimaste), colloquial expressions (uno sconto esagerato, a ginormous discount), local idioms (ce l'avevo sul groppone, literally "I had them on my back", i.e. I could not shake them off), discourse markers (dé) and interjections $(e h)$.

By way of conclusion, it could be said that the English subtitles of La prima cosa bella manage to convey the meaning of the SL dialogues, but tend to standardise most of the features that deviate from the linguistic norm: all the characters appear to speak standard English, and nuances are flattened.

\section{Tutti i santi giorni - Every Blessed Day}

Tutti $i$ santi giorni is loosely based on the novel La generazione (2012), written by Simone Lenzi who also collaborated with Paolo Virzì and Francesco Bruni on the screenplay.

Guido (Luca Marinelli) and Antonia (Thony) are a young couple with contrasting personalities and working schedules: he is a particularly sensitive and good-hearted young man who is well-educated and interested in hagiography, with a night job as a concierge in a hotel, while she is a singer and guitarist but works as an employee at a car rental during the day and is extremely passionate and often irrational. Tutti $i$ santi giorni is the story of what happens to them when they decide to try for a baby and Antonia cannot get pregnant.

The linguistic landscape in this film is quite varied, because Guido comes from Tuscany, while Antonia is Sicilian, but they live together in Rome. Therefore the dialogues are permeated by different accents, i.e. Florentine, Sicilian and Roman dialects and regiolects, which represent quite a 
challenge for the translator/adaptor, especially in subtitling, a specific mode of audiovisual translation where aural features are totally absent. In the following sections, the analysis will focus on idiolectal features and how the various dialects and regiolects have been transposed in the English subtitles.

\subsection{Idiolects, dialects and regiolects}

The present section deals with the different idiolects that can be found in this film, starting from those of the two main characters, Guido and Antonia, and the way in which they have been transposed in the English subtitles.

As was anticipated in the previous section, Guido is erudite and interested in Latin, Greek and protochristian hagiography, i.e. the lives of saints. In line with his character, he also carefully chooses old-fashioned expressions in any kind of situational context and regardless of his interlocutors. For instance, example (6) below shows the conversational exchange with his neighbour, Marcello, the typical Roman chav speaking with a strong Roman accent, which highlights Guido’s high register.

(6)

\begin{tabular}{|l|l|c|}
\hline MARCELLO & Di che squadra sei? & $\begin{array}{c}\text { - What's your favorite team? } \\
\text { - Ø I'm no soccer aficionado. }\end{array}$ \\
\hline GUIDO & $\begin{array}{l}\text { Mah, io non è che sia un acceso } \\
\text { tifoso. Da ragazzo avevo una certa } \\
\text { simpatia per l'Atalanta. }\end{array}$ & $\begin{array}{c}\text { As a kid I liked Bergamo's team, } \\
\text { Atalanta... }\end{array}$ \\
\hline MARCELLO & Atalanta? Ma non sei toscano te? & Ø Aren't you Tuscan? \\
\hline GUIDO & $\begin{array}{l}\text { No, per via che è il nome di una dea } \\
\text { greca, una divinità cacciatrice, } \\
\text { abbastanza assimilabile ad } \\
\text { Artemide, non so se avete presente. }\end{array}$ & $\begin{array}{c}\emptyset \text { It's the name of } \\
\text { the Greek goddess of hunting, }\end{array}$ \\
\hline $\begin{array}{l}\text { MARCELLO } \\
\text { to his friends }\end{array}$ & $\begin{array}{l}\text { V'avevo detto che Guido era un } \\
\text { personaggione, raga'! Ma io v'avevo } \\
\text { detto, il sor Guido, è un macello! }\end{array}$ & $\begin{array}{l}\text { Lairly similar to Artemis, } \\
\text { perhaps you've heard... }\end{array}$ \\
\hline
\end{tabular}

As can be noticed in (6), to answer Marcello's question Guido uses the expression acceso tifoso (roughly, "passionate fan"), which is translated as soccer aficionado in the subtitles: here the 
American term soccer was preferred to avoid ambiguity (American football is a different sport), but the subtitle is a fairly good attempt to render the same level of sophistication in the lexical choices of the source text. Conversely, the choice to render avevo una certa simpatia per with the neutral verb like, instead of 'I was partial to', seems to flatten Guido's way of speaking. The huge difference between the two interlocutors can be observed in Marcello's final turn, which is characterised by a brusque downgrade in register, as it is full of colloquialisms and regional idiomatic expressions: repetitions, the apocope of the final syllable in the vocative raga' (> "ragazzi"), the use of the adversative $m a$ at the beginning of the sentence, the abbreviated form of "signore" (sor) before the proper name, and, finally, the idiomatic è un macello, translated as he's a trip. It is worth noticing that in the conversational exchange in (6) the general tendency in translation is to omit several verbal items, with few exceptions, e.g., in Guido's first turn, there is an addition in the subtitle in order to explain that Atalanta is not a Tuscan football team, but it is based in the north of Italy, so as to provide a foreign audience with enough information to understand what comes next.

Overall, in other exchanges Guido's use of old-fashioned expressions is to an extent rendered in the English subtitles: for example, the interjection perdinci with dagnabit, or the recurrent expression a onor del vero with truth to be told. Moreover, there are other typically Tuscan features that are used by both Guido and his family in a scene where Guido and Antonia go visit them: diminutive suffixes in proper names, e.g. Guidino, Rossellina (proper names are either normalised or totally omitted in the subtitles), in adverbial phrases (e.g. pianino $>\varnothing ;$ a modino, translated as behave) and in nouns such as la mi' bimbina (the subtitle reproduces the diminutive by adding the hypocoristic suffix '-ie' in my sweetie ); interjections, such as ovvia giù (translated with the standard alright then) and ohi (deleted in the TT); and finally, the double dative pronoun a me $m i$ and specific dialectal terms like garbare and bischero, which are standardised in the subtitles, i.e., like and silly, respectively. 
When analysing Antonia's idiolect, we must bear in mind that she is an artist, a talented musician, singer and song writer, and her character is passionate, blunt and often irrational, thus representing the stereotypical woman from the south of Italy, even though she tries to escape from that mentality. She uses several colloquial dialectal terms and taboo words such as minchiata, scimunita, scassare, which are generally either rendered with swearwords or neutral terms in the English subtitles (i.e. fuck up, moron and criticize, respectively), and some typical idiomatic expressions, among which andare giù (meaning "to go home down south"), which has a strong cultural connotation that is totally lost in the English subtitle, where the neutral term visit was employed.

As well as occasional isolated dialectal terms, Antonia also uses Sicilian dialect proper to speak to her parents, Domenico and Rosetta, when they go to Rome from Sicily to visit her and meet her fiancé Guido, as in example (7) below.

(7)

\begin{tabular}{|c|c|c|}
\hline $\begin{array}{l}\text { ANTONIA to } \\
\text { Rosetta }\end{array}$ & Va' 'ssettate, siediti! & - Sit down. $\varnothing$ \\
\hline $\begin{array}{l}\text { DOMENICO } \\
\text { to Antonia }\end{array}$ & $\begin{array}{l}\text { Non t'arrisicare a trattare } \\
\text { accussi a to matre! }\end{array}$ & Don't treat your mom like that! \\
\hline ANTONIA & $\begin{array}{l}\text { È idda che ci ave i manu unne è } \\
\text { ghiè, per farmi pesare che c'è } \\
\text { disordine! }\end{array}$ & $\begin{array}{l}\text { She keeps cleaning up } \\
\text { to remind me that I'm messy. }\end{array}$ \\
\hline ROSETTA & Ma io ti volevo solo aiutare...! & $\varnothing$ I wanted to help. \\
\hline ANTONIA & $\begin{array}{l}\text { Ma non c'è bisogno che me lo fai } \\
\text { notare, lo so che qua non è tutto a } \\
\text { specchio come a casa vostra, } \\
\text { travagghiamo tutti i due e 'unn } \\
\text { avemu la cammeriera! Ch'aio a } \\
\text { fare, m'aiu ammazzare? }\end{array}$ & $\begin{array}{l}\text { No need to remind me, I know } \\
\text { my home isn't spotless like yours. } \\
\text { We work } \varnothing, \text { I can't go crazy cleaning! }\end{array}$ \\
\hline $\begin{array}{l}\text { DOMENICO } \\
\text { to Antonia }\end{array}$ & $\begin{array}{l}U \text { viri comu si? Idda mischina } \\
\text { niente ti risse a tia! }\end{array}$ & $\begin{array}{c}\text { Leave her alone, } \\
\text { she didn't say anything. }\end{array}$ \\
\hline
\end{tabular}

The first thing that can be noticed is that the subtitled text is strongly reduced with respect to the original dialogue (cf. words and expressions in italics in the original soundtrack that are totally omitted in the subtitles), so that several utterances in Sicilian dialect are either obliterated or standardised. Moreover, even the code-switching from standard Italian to Sicilian dialect is totally 
lost in the subtitles.

Finally, a few observations on the Roman regiolect spoken by several characters in the film (as it is set in Rome) are in order. As D’Achille (2011) states, Roman has its own peculiarities, which can be found in the following excerpt (8), a conversational exchange at the birthday party of Michelle, the daughter of Guido and Antonia's neighbours, Patrizia and Marcello.

\begin{tabular}{|c|c|c|}
\hline $\begin{array}{l}\text { (reads) } \\
\text { to grandmother }\end{array}$ & $\begin{array}{l}\text { E arivata pure zia Sabrina, } \\
\text { facciamole vedere che c’è } \\
\text { nel regalo. Non ce posso } \\
\text { crede'! Ma che davero? } \\
\text { Cioè, stupendo, non } \\
\text { dovevate! Ce sta pure il } \\
\text { nome scritto! } \\
\text { Ma allora se' de coccio! } \\
\text { Ma nun se scrive così! }\end{array}$ & $\begin{array}{l}\text { Aunt Sabrina is here, } \\
\text { let's open it up now. } \\
\text { No way, I don't believe it! } \\
\text { Really? } \\
\text { This is like amazing, } \\
\text { you shouldn't have! } \\
\text { It's got her name on it. } \\
\varnothing \text { Damn you're dense! } \\
\text { This isn't how it's spelled! }\end{array}$ \\
\hline GRANDMOTHER & $\begin{array}{l}\text { No, guarda, sui documenti } \\
\text { ce sta scritto così, Caiozzi } \\
\text { Miscèl. }\end{array}$ & $\begin{array}{l}\varnothing \text { On her birth certificate } \\
\text { it says Miscèl Caiozzi. }\end{array}$ \\
\hline PATRIZIA & $\begin{array}{l}\text { Ma quello è tu' fijo che ha } \\
\text { toppato all'anagrafe! }\end{array}$ & $\varnothing$ Your son messed up at town hall. \\
\hline GRANDMOTHER & E che te posso fa'? & $\varnothing$ \\
\hline PATRIZIA & $\begin{array}{l}\text { Se scrive col ci-acca, 'sto } \\
\text { deficiente! }\end{array}$ & $\begin{array}{c}\text { - It's with a "ch", you imbecile! } \\
\text { - Hell no... Ø }\end{array}$ \\
\hline $\begin{array}{l}\text { MARCELLO to } \\
\text { Patrizia }\end{array}$ & $\begin{array}{l}\text { A bella, nun ce prova', } \\
\text { vie' qua, vie'. Faje vede', } \\
\text { faje vede' qua che ce sta } \\
\text { scrittto. }\end{array}$ & - $\varnothing$ Show them what it says here! \\
\hline PATRIZIA & Che? A ridaje! & - Not again, stop! \\
\hline $\begin{array}{l}\text { MARCELLO } \\
\text { (showing her tattoo } \\
\text { to everybody) }\end{array}$ & $\begin{array}{l}\text { Faje vede', faje vede' qua } \\
\text { che ce sta scritto, } \\
\text { "Michele". Adesso me dici } \\
\text { chi è 'sto Michele. Dai, } \\
\text { chi è, mi' cugino? Mamma } \\
\text { mia, si scrive esse-ci-acca, } \\
\text { come la Hunziker. Come } \\
\text { te lo devo di'? A Patri', } \\
\text { sei veramente ignorante. }\end{array}$ & $\begin{array}{c}\varnothing \text { Show them what is says: "Michele". } \\
\varnothing \text { Who's this Michele guy, } \varnothing \text { my cousin? } \\
\varnothing \text { It's with “sch", } \\
\text { like that Mischelle Hunziker. } \\
\varnothing \text { I give up, you're so ignorant. }\end{array}$ \\
\hline
\end{tabular}

The analysis of the source text shows a wide set of typical features characterising the Roman 
regiolect, at different linguistic levels. Apart from some lexical choices - i.e. the use of the verb stare instead of essere ("to be" in English), e.g. ce sta pure il nome; the interjection ma che da(v)vero?, and the idiom ma se' de coccio!, rendered with damn, you're so dense in the subtitles several linguistic phenomena can be observed at the phonetic level: the preservation of protonic "e" in phonosyntax (e.g. $c i>c e$ in $c e s t a$ ), the change of the palatal $[\Lambda]$ into the semivowel or jod [j] (e.g. figlio > fijo), the aphaeresis or loss of the initial accented syllable (e.g. questo > 'sto), and, finally, the apocope of the final syllable in infinitives (e.g. vedere > vede') and in proper names (e.g. Patrizia $>$ Patri'). One last typical feature that is worth noticing is the use of the address form "a" in vocatives (e.g. a Patri'). If we compare the original dialogue with all the marked expressions highlighted in bold with the subtitles in the right-hand column, the general impression is that the translation tends towards deletion and standardisation.

\section{Il capitale umano - Human Capital}

The third film under analysis is Il capitale umano. Like Tutti i santi giorni, it is also based on a novel, but one with a totally different setting. Stephen Amidon's homonymous novel, Human Capital (2004), takes place in wealthy Connecticut at the beginning of the $21^{\text {st }}$ century, whereas Virzì moved the setting to an imaginary Brianza, as the film was actually shot in Varese, in the north of Italy. All the characters speak with a northern accent, more or less prominent, depending on the character and the situation.

The destinies of two families, upper class Bernaschi, living in an amazing villa in fictional Ornate, and middle-class Ossola, led by social climber Dino, are irrevocably tied together after a cyclist is hit off the road by a jeep on the night before Christmas Eve.

The film has two groups of opposing characters, the adults and the young. The former are all driven by money and are essentially empty human beings. Dino Ossola (Fabrizio Bentivoglio), for example, is pushed by a compelling drive to move upwards socially and does not realise he is losing all his assets and his family's reputation. All the adults are immature and are parents only in role but 
not in their true identity. By contrast, among the adolescents there are heroic characters like Serena, quite different from her father Dino, and Luca, the alternative, proletarian artist, who is the beautiful soul of the story.

\subsection{Features of neostandard Italian in Il capitale umano}

In Il capitale umano Virzì and his scriptwriters successfully captured the average register that is spoken by Italians belonging to different milieux and sociolinguistic groups, thus offering the audience a realistic portrait of contemporary life in a small Italian provincial town. The main characters use the so-called Italian "neo-standard" (Berruto, 1987; Sobrero, 1992), spoken with a northern accent, which may be more or less marked according to age group and social class, but is easily recognised all over Italy as Lombard.

Most of the characters in Il capitale umano are distinguished by their idiolects, which offer a kaleidoscope of the neo-standard, enriched from time to time with features belonging either to youth language or to regional varieties. Dino, in particular, because he is quite talkative, with a tendency to go overboard when he is emotionally engaged, exemplifies the widest possible array of features.

Among the most frequent morphological features there is a simplification of verb tenses and moods, which is reflected in a limited number of tenses used with a plurality of functions (e.g. the present is also used to refer to the future) and in the tendency to replace mood with tense, for example the imperfect tense is used to replace the conditional and subjunctive (Se ti dicevo la verità non me li davi neanche morto, "If I told you the truth, no way you would give it [= the money] to me"). Another typical element is the use of che as a passepartout conjunction. Che operates as a generic subordinator introducing a secondary clause with causal, concessive, temporal or final value, such as in the following examples: $V a$ ', che il papà si preoccupa, "Go that your dad worries about you"; Gerard, li fai accomodare tu in sala riunioni che io arrivo subito?, "Gerard, let them into the meeting room that I'll join you soon". Personal pronouns too are redefined according to 
neo-standard rules, with some forms being selected and over-extended, e.g. te, used for the subject case as well (cf. e.g. 9), and gli, used regardless of gender and number (e.g. I bambini [...] li ho portati dalla nonna, non gli ho detto niente, 'The kids, I took them to grandma's, I haven't told him anything). Most often double dative pronouns are used for emphatic effect, creating strings such as a me mi or a te ti (Te a me mi hai sempre sottovalutato eh?, "You have always undervalued me").

New oral trends in the syntactic domain mainly concern word order. In conversation, the unmarked order SVOA is strategically altered to give special communicative prominence to certain constituents. Marked syntactic constructions include left and right dislocation, clefts and pseudoclefts and presentative structures (e.g. Mio padre se lo prende nel culo il premio Cottafavi!, "My father, he can stick the Cottafavi prize up his ass!"').

The lexical dimension is also richly re-defined in the neo-standard, as novel, expressive vocabulary is looked for to contrast the 'wear' effect that lexical units inevitably undergo. In narrative texts this dimension is the one that contributes most to sketch characters' identity and stylise each of them in a unique way. Two main trends can be observed: on the one hand, a whole series of traits converge towards hyperbolic expressions, with an excessive use of superlatives, extreme case formulations (e.g. nessuno, tutti), alterative suffixes, exaggerated adjectival qualifications, as typical of youth language and trendy speech in general (Cortelazzo, 1994; Coveri, 1993; Radtke, 1993a, 1993b); on the other, there is an equally wide use of mitigating devices aimed at avoiding possible conflictual sequels and distressing subjects (e.g. use of shortened forms of names, diminutives, vague language, etc.).

\subsection{Idiolects: Dino and Davide}

From a linguistic point of view, Dino and Davide are the most interesting characters, although with rather different roles. Dino is one of the leading characters, whose personality and development are gradually disclosed in the film chapters. By contrast, Davide, Luca's uncle (the unlucky guy who involuntarily runs over the biker at the beginning of the film), who strives to appear attentive and 
fond of his nephew but is really interested in his money, is a minor character. However, both are skilfully portrayed through the language they speak, a mixture of juvenile traits, aimed at sounding bourgeois in Dino's case, and casual and relaxed in Davide's. Some samples of their speech are discussed in what follows.

The first example contains a complete collection of all of Dino's typical stylistic features.

\begin{tabular}{|c|c|c|}
\hline DINO & $\begin{array}{l}\text { Senti Giova, no, volevo dirti... } \\
\text { magari adesso non è il momento, } \\
\text { ma visto che è scattato questo } \\
\text { feeling tra noi due, no?!.. [...] } \\
\text { Poi ci sono anche i ragazzi... ma } \\
\text { quanto sono belli i ragazzi } \\
\text { insieme, eh?! [...] Uè, figa! Ma } \\
\text { cosa fai, mi leggi nel pensiero? } \\
\text { Sì! Io pensavo a una quota, } \\
\text { così... però insomma... [...] } \\
\text { Grande Giova! Siamo una } \\
\text { forza noi due! }\end{array}$ & $\begin{array}{l}\text { Hey } \varnothing, \text { I was wondering... } \\
\text { Now might not be the right time. } \\
\text { but seeing there's a good vibe } \\
\text { between us... [...] } \\
\text { Not to mention the kids... } \\
\text { Aren't they adorable together? [...] } \\
\text { Wow, you can read my mind! } \\
\text { Yes, I was thinking about } \\
\text { a small share } \varnothing .[\ldots] \\
\text { My man, Giovanni! } \\
\text { You and I are a powerhouse. }\end{array}$ \\
\hline
\end{tabular}

Dino uses the shortened form of his interlocutor's name to reduce the social distance and get closer to him. The attempt at bridging distance is also shown by the inclusive possessive our, which consolidates vicinity, anticipating Dino's wish to become Giovanni’s business partner. Here the English subtitles could have used the possessive as the unmarked option. Then Dino uses the adjective belli referring to his daughter and Giovanni's son, extending its semantic meaning from their physical appearance to their love story. The adjective itself is very frequent in Italian, very often with this extension of meaning from the physical to the moral dimension that is rendered more explicit in the subtitles. When Giovanni understands Dino's predictable plan, Dino shows his surprise with an interjection, $u \grave{e}$, typical of Northern Italy, further reinforced by the expletive figa (a northern variant of fica, literally "cunt"), a stock phrase that often appears in youth language, 
reasserting at the same time his (contrived) offhand and trendy ways. The interjection wow that is used in the subtitles only reproduces the meaning of surprise, reducing the force of the utterance, even more so because in English "wow" can either refer to positive or negative reactions. Finally, in the last turn Dino again resorts to the very widespread (and thus partially de-semanticised) adjective grande, often employed in combination with proper names. The value of grande is "cool, great", and the appreciation is immediately projected from Giovanni onto we, the newly formed partnership between Dino and Giovanni, siamo una forza noi due. In the subtitles the isotopy of power is preserved with the element powerhouse, but a more popular, colloquial adjective would have been more effective, for example awesome, considering its circulation among youngsters.

Young people and Davide (Luca's slimy uncle), who is unruly and addicted to drugs, have a jargon of their own, where the traits that are mimicked by Dino are more lavishly and spontaneously employed. In what follows there is an example of interaction taking place between Davide and Serena. Serena would like to see Luca but he is asleep so she is welcomed by Davide.

(10)

\begin{tabular}{|l|l|c|}
\hline DAVIDE & $\begin{array}{l}\text { Eh! Allora ci vieni a trovare, eh? } \\
\text { Magari un po' dopo, eh? Ospite } \\
\text { nostra! Scommetto che Luca avrebbe } \\
\text { un piacere della Madonna... }\end{array}$ & $\begin{array}{c}\text { You should come visit us then! } \\
\text { Maybe after we've settled. }\end{array}$ \\
\hline SERENA & Magari! & $\begin{array}{r}\text { You'll be our guest, } \\
\text { Luca will be thrilled. }\end{array}$ \\
\hline DAVIDE & Eh! & $\begin{array}{c}\text { - That'd be nice, thanks. } \\
\text { - My pleasure, go wake him up. }\end{array}$ \\
\hline SERENA & Grazie mille, gentilissimo! \\
\hline $\begin{array}{l}\text { DAVIDE } \\
\text { laughs) }\end{array}$ & $\begin{array}{l}\text { Figurati! Vai a svegliarlo va'! Che è } \\
\text { narcotizzato, cazzo! Senti digli che esco } \\
\text { anch'io, eh? Che c'ho un puntellino, va } \\
\text { bene? }\end{array}$ & $\begin{array}{r}\text { He's fucking comatose. } \\
\text { Tell him I'm going out, } \\
\text { I've got a little meeting. }\end{array}$ \\
\hline
\end{tabular}

Davide's linguistic repertoire, spoken with a northern accent, includes a whole array of traits: hyperbolic language, regional expressions, expressive suffixes. The first upgrader, un piacere della Madonna (literally "of the Virgin") is completely erased, removing both the intensity and the local colour of the expression, which is deemed colloquial if not downright vulgar. The word puntellino (literally "a prop + DIMINUTIVE suffix") refers to a meeting Davide has, but is limited to regional 
use: the diminutive adds some further shades of meaning, e.g. the non-importance of the fact alluded to. Davide's elusive allusion to something that is not explicitly explained but is perceivable through his verbal and nonverbal behaviour should have been retained. "A little meeting" only removes importance from the event but does not connote it as something scheming or illicit.

\section{Discussion and Conclusions}

If transposing dialectal features is always challenging, it is even more so when these traits have to be encoded in a different medium, i.e. what is expressed orally is turned into written signs. When there is much source language variety in film dialogues, critics notice that diversity is rarely preserved in target language subtitles (Assis-Rosa, 2001; Bartoll, 2006; Ellender, 2015; Heiss, 2004). Usually, anything which is non-standard is reduced to a neutral register, with severe losses in the protagonists' characterisation and in the development of the film's narrative, ultimately resulting in a stunted appreciation of the linguistic and cultural specificity of the product (Ellender, 2015). By contrast, the replacement of one dialect with another results in a loss of the original characterisation (Jäckel, 2001) or in a "relocation of the characters' identities" (Mével, 2007, p. 54), as Ellender (2015) highlights referring to the experimental solution adopted subtitling the French verlan (a socially marked French argot) in La Haine ${ }^{7}$ into African-American Vernacular English (AAVE). In this and similar cases, it is debatable whether the connotative values attached to a marked variety in the source language are comparable to those of another in the target language, with the additional shortcoming of producing an evident discrepancy between what can be seen on the screen and what can be read in the subtitles.

Some general trends have emerged from the analysis of the three films under consideration: markers of orality such as repetitions, vocatives, hedges, discourse particles, and vague language are generally deleted; dialects and regiolects are mostly standardised, even though occasionally

\footnotetext{
${ }^{7}$ A film released in 1995 by French filmmaker and actor Mathieu Kassowitz, which depicts the difficult lives of immigrant families in the multi-ethnic borders of Paris.
} 
some substandard forms are preserved locally; generally, idiosyncratic usages of the language are obliterated or at best only partly represented (e.g. Anna and Guido's use of diminutives and Dino's use of both diminutives and hyperbolic language, Guido's archaic or more formal terms and phrases); and, finally, the only substandard feature that is represented in the subs, albeit in a reduced form and with a loss of 'local flavour', is foul language. The latter aspect seems to be a recurring pattern in the translation of dialects in films, as shown, for example, by Petillo (2012). The switch between Italian, regional Italian and local dialect is not reproduced, but there is an attempt at preserving the liveliness of the original informal register by means of declarative questions and marked lexical choices. However, the discussion of the examples presented in the paper has also shown that in some cases it would be theoretically possible to give the target language viewers at least a glimpse of the most characteristic features of the SL dialogues. Of course, this would imply giving subtitlers sufficient time to devise creative and accurate translation solutions. In addition, another possibility would be adding some explanations in the paratext, for example in the so-called DVD's Extras (Ellender, 2015). The use of explanatory notes is often criticised, but when it comes to DVDs, Díaz-Cintas (2005) agrees that "there is no obstacle to the incorporation of more precise information on the translation as part of the bonus material" (p. 26).

\section{References}

Accardo, A., \& Acerbo, G. (2010). My name is Virzì. L'avventurosa storia di un regista di Livorno [My name is Virzì. The adventurous story of a director from Livorno]. Genova: Le Mani. Amidon, S. (2004). Human capital. New York: Farrar, Straus and Giroux.

Antonini, R. (2005). The perception of subtitled humour in Italy: An empirical study. In D. Chiaro (Ed.), International Journal of Humour Research, Special Issue Humour and Translation, 18(2), 209-225. doi: https://doi.org/10.1515/humr.2005.18.2.209

Assis-Rosa, A. (2001). Features of oral and written communication in subtitling. In Y. Gambier \& H. Gottlieb (Eds.), Multimedia translation: Concepts, practice and research (pp. 213-222). Amsterdam / Philadelphia: Benjamins. 
Bartoll, E. (2006). Subtitling multilingual films. In EU High-level Conference Series. MuTra 2006 - Audiovisual Translation Scenarios: Conference Proceedings. Retrieved from: http://www.euroconferences.info/proceedings/2006_Proceedings/2006_Bartoll_Eduard.pdf

Berruto, G. (1987). Sociolinguistica dell'italiano contemporaneo [Sociolinguistics of contemporary Italian]. Roma: Carocci.

Chaume, F. (2012). Audiovisual translation: Dubbing. Manchester: St. Jerome.

Cortelazzo, M. A. (1994). Il parlato giovanile [Youth speech]. In L. Serianni \& P. Trifone (Eds), Storia della lingua italiana [A history of the Italian language] (pp. 291-317). Torino: Einaudi.

Coveri, L. (1993). Novità del/sul linguaggio giovanile [News on youth language]. In E. Radtke (Ed.), La lingua dei giovani [The language of youth] (pp. 35-47). Tübingen: Narr.

D’Achille, P. (2011). Italiano di Roma [Italian in Rome]. In Enciclopedia dell'italiano Treccani [Treccani Encyclopoedia of Italian], online. Retrieved from http://www.treccani.it/enciclopedia/italiano-di-roma_(Enciclopedia-dell'Italiano)/

De Meo, M. (2012). Subtitling dialects: Strategies of socio-cultural transfer from Italian into English. In S. Bruti \& E. Di Giovanni (Eds.), Audiovisual translation across Europe. An ever-changing landscape (pp.79-96). Bern: Peter Lang.

Díaz-Cintas, J. (2005). Back to the future in subtitling. In H. Gerzymisch-Arbogast \& S. Nauert (Eds.), EU High Level Scientific Conferences, Marie Curie Euroconferences MuTra: Challenges of Multidimensional Translation (pp. 16-32). Saarland, University Germany, Advanced Translation Research Center (ATRC).

Díaz-Cintas, J., \& Remael, A. (2007). Audiovisual translation: Subtitling. Manchester: St. Jerome. Ellender, C. (2015). Dealing with difference in audiovisual translation. Subtitling linguistic variation in films. Bern: Peter Lang.

Giordano, F. (2011). Virzì regista glocale [Virzì, a glocal director]. In F. Zecca (Ed.) Lo spettacolo del reale. Il cinema di Paolo Virzì [Filming reality. Paolo Virzì’s cinema] (pp. 75-88). Ghezzano: Felici editore.

Heiss, C. (2004). Dubbing multilingual films: A new challenge?. Meta, 49(1), 208-220. doi: 10.7202/009035ar

Jäckel, A. (2001). The subtitling of La Haine: A case study. In Y. Gambier \& H. Gottlieb (Eds.), Multimedia translation: Concepts, practices and research (pp. 223-35). Amsterdam / Philadelphia: John Benjamins.

Lenzi, S. (2012). La generazione [The generation]. Milano: Dalai Editore. 
Malavasi, L. (2011). Il realismo di Virzì: Una questione di stile [Virzì’s realism: A question of style]. In F. Zecca (Ed.) Lo spettacolo del reale. Il cinema di Paolo Virzì [Filming reality. Paolo Virzì's cinema] (pp. 89-97). Ghezzano: Felici editore.

Mével, P.-A. (2007). The translation of identity: Subtitling the vernacular of the French cite. MHRA Working Papers in the Humanities, 2, 49-56. Retrieved from http://www.mhra.org.uk/publications/wph-2

Petillo, M. (2012). La traduzione audiovisiva nel terzo millennio [Audiovisual translation in the third millenium]. Milano: FrancoAngeli.

Radtke, E. (Ed.) (1993a). La lingua dei giovani [Youth language]. Tübingen: Narr.

Radtke, E. (1993b). Varietà giovanili [Youth varieties]. In A. Sobrero (Ed.) Introduzione all'italiano contemporaneo. La variazione e gli usi [An introduction to contemporary Italian. Variation and use]. (pp. 191-235). Roma / Bari: Laterza.

Ranzato, I. (2010). Localising Cockney: Translating dialect into Italian. In J. Díaz-Cintas, J. Neves, \& A. Matamala (Eds.), New insights into audiovisual translation and media accessibility. Media for All 2 (pp. 109-122). Amsterdam: Rodopi.

Sobrero, A. (1992). L'italiano di oggi [Contemporary Italian]. Roma: Istituto della Enciclopedia Italiana Treccani.

Tortoriello, A. (2012). Lost in subtitling? The case of geographically connotated language. In S. Bruti \& E. Di Giovanni (Eds.), Audiovisual translation across Europe. An ever-changing landscape (pp. 97-1116). Bern: Peter Lang.

\section{Filmography}

Il capitale umano [Human capital] (2014), Paolo Virzì, Italy.

La haine [Hate] (1995), Mathieu Kassowitz, France.

La prima cosa bella [The first beautiful thing] (2010), Paolo Virzì, Italy.

Tutti $i$ santi giorni [Every blessed day] (2012), Paolo Virzì, Italy. 


\begin{tabular}{|l|c|l|c|c|c|}
\hline \multicolumn{1}{|c|}{ Film Title } & Year & \multicolumn{1}{|c|}{ Scriptwriters } & Duration & $\begin{array}{c}\text { Tokens } \\
\text { (ITA) }\end{array}$ & $\begin{array}{c}\text { Tokens } \\
\text { (ENG) }\end{array}$ \\
\hline $\begin{array}{l}\text { La prima cosa bella } \\
\text { The First Beautiful Thing }\end{array}$ & 2010 & $\begin{array}{l}\text { Paolo Virzì, Francesco Bruni, } \\
\text { Francesco Piccolo }\end{array}$ & $118^{\prime}$ & 13,595 & 11,181 \\
\hline $\begin{array}{l}\text { Tutti } \text { i santi giorni } \\
\text { Every Blessed Day }\end{array}$ & 2012 & $\begin{array}{l}\text { Paolo Virzì, Francesco Bruni, } \\
\text { Simone Lenzi }\end{array}$ & $102{ }^{\prime}$ & 9,926 & 7,742 \\
\hline $\begin{array}{l}\text { Il capitale umano } \\
\text { Human Capital }\end{array}$ & 2014 & Paolo Virzì, Francesco Bruni, & 109 & 11,395 & 9,452 \\
\hline
\end{tabular}

Table 1. The three films under analysis 